\title{
First report of Davaneidae and Strongylida parasitizing Ramphocelus carbo (Aves: Passeriformes: Thraupidae) in the southwest of the Brazilian Amazon region
}

\author{
Primeiro relato de Davaneidae e Strongylida parasitando Ramphocelus \\ carbo (Aves: Passeriformes: Thraupidae) no sudoeste da Amazônia \\ brasileira
}

Leandro Siqueira de Souza1* (1), Edson Guilherme ${ }^{2,3}$, Saba Gul ${ }^{4}$, Angela Maria Fortes de Andrade ${ }^{5}$, Francisco Glauco de Araújo Santos ${ }^{3}$

${ }^{1}$ Laboratório de Apoio à Vida Silvestre, Universidade Federal do Acre - UFAC, Rio Branco, AC, Brasil

${ }^{2}$ Laboratório de Ornitologia, Universidade Federal do Acre - UFAC, Rio Branco, AC, Brasil

${ }^{3}$ Centro de Ciências Biológicas e da Natureza, Universidade Federal do Acre - UFAC, Rio Branco, AC, Brasil

${ }^{4}$ Programa de Pós-graduação em Biologia Parasitária, Instituto Oswaldo Cruz - FIOCRUZ, Manguinhos, Rio de Janeiro, RJ, Brasil

${ }^{5}$ Programa de Pós-graduação em Sanidade e Produção Animal Sustentável na Amazônia Ocidental, Universidade Federal do Acre - UFAC, Rio Branco, AC, Brasil

How to cite: Souza LS, Guilherme E, Gul S, Andrade AMF, Santos FGA. First report of Davaneidae and Strongylida parasitizing Ramphocelus carbo (Aves: Passeriformes: Thraupidae) in the southwest of the Brazilian Amazon region. Braz J Vet Parasito/ 2020; 29(1): e016719. https://doi.org/10.1590/S1984-29612019105

\begin{abstract}
In Brazil, species of the genus Ramphocelus with the presence of various endoparasites have already been reported. Coccidia have been the parasites most frequently found. All species of this genus have similar habitats and ecological niches, which makes parasite transmission easy. The aim of this study was to diagnose the presence of endoparasites in fecal samples from specimens of Ramphocelus carbo that were caught in the Cazumbá-Iracema Extractive Reserve (Cazumbá Resex), in the State of Acre. The specimens $(n=30)$ were caught in mist nets arranged in different ecosystems of the Reserve. After identification, the bird specimens were placed in cloth bags for a maximum of 30 minutes to collect feces. Among the 22 samples collected, $63.63 \%(n=14)$ were positive for endoparasites. The coccidia were the parasites most frequently. Helminths belonging to Ascaridiidae (Nematoda), Strongylida (Nematoda) and Davaneidae (Cestoda) were recorded for the first time in $R$. carbo in the State of Acre. Parasites belonging to Strongylida and Davaneidae were recorded for the first time in a species of Ramphocelus. These findings add information on the parasitic fauna of wild birds, since in the Amazon region there are few studies on this subject.
\end{abstract}

Keywords: State of Acre, wild birds, coccidia, reserva extrativa de Cazumbá-Iracema, gastrintestinal parasites.

\section{Resumo}

No Brasil, espécies do gênero Ramphocelus ja foram relatadas com a presença de vários endoparasitos, sendo os coccídios os parasitos mais frequentes. Todas as espécies do gênero possuem habitats e nichos ecológicos semelhantes, facilitando a transmissão desses parasitos. O presente estudo teve como objetivo diagnosticar a presença de endoparasitos em amostras fecais de Ramphocelus carbo capturadas na Reserva Extrativista Cazumbá-Iracema (Resex do 
Cazumbá), localizada no estado do Acre. Os espécimes ( $n=30)$ foram capturados em redes de neblina dispostas em diferentes ecossistemas da Reserva. Após a identificação das aves, os espécimes foram colocadas em sacos de pano por no máximo 30 minutos para coleta das fezes. Das 22 amostras coletadas, 63,63\% ( $n=14)$ foram positivas para endoparasitas. Os coccídíos foram os parasitos mais frequentes. Os helmintos Ascaridiidae (Nematoda), Strongylida(Nematoda) e Davaneidae (Cestoda) foram registrados pela primeira vez em $R$. carbo, no estado do Acre. Strongylida e Davaneidae são registrados pela primeira vez em uma espécie pertencente a Ramphocelus. Esses achados acrescentam informações sobre a fauna parasitária de aves silvestres, pois na Amazônia existem poucos estudos nessa área.

Palavras-chave: Estado do Acre, aves silvestres, coccídeos, reserva extrativa de Cazumbá-Iracema, parasitos gastrintestinais.

\section{Introduction}

Ramphocelus (Aves: Thraupidae) includes 10 species (Hilty, 2018), of which only three (R. carbo, R. nigrogularis and R. bresilius) occur in Brazil (Piacentini et al., 2015).

The silver-beaked tanager (Ramphocelus carbo, Pallas 1764) is widely distributed in South America. The occurrence of these species in Brazil extends from the Amazon eastwards to Piauí and southwards to western Parana and southern Mato Grosso do Sul (Carvalho, 1957; Hilty, 2018). These birds have been found all over the state of Acre (Guilherme, 2016), as well as in other Brazilian Amazon states (Sick, 1997).

This species forages in diverse Amazon ecosystems such as in bushes at forest edges, overgrown clearings, plantations around dwellings and shrubby dense vegetation along riverbanks in wetlands and, especially, in anthropized areas (Hilty, 2018).

Among the species of the genus Ramphocelus, Ramphocelus bresilius is the one most frequently reported as having the presence of endoparasites (Berto et al., 2008; Berto et al., 2009; Lopes et al., 2013; Rojas, 2016). The presence of these endoparasites is directly related to these birds' behavior, nutrition and reproductive development, which lead to secondary infections in all tissues and organs (Freitas et al., 2002; MariettoGoncalves et al., 2009). Such infections have serious consequences for the preservation of bird species and, especially, those that are threatened with extinction (Costa et al., 2010).

Despite the wide distribution of $R$. carbo in the Amazon region, there are only two studies reporting endoparasites in these species (Brito et al., 2017; Boughton et al., 1938). Hence, it is opportune to expand the knowledge of its parasitic fauna in this biome. From this perspective, the aim of this study was to diagnose occurrences of endoparasites in fecal samples from specimens of $R$. carbo that were caught in the Reserva Extrativa de Cazumbá-Iracema in the State of Acre.

\section{Materials and Methods}

This investigation was carried out in the "Comunidade Cuidado" ("Care Community") in the Cazumbá Resex, which is located in the Municipality of Sena Madureira, in the eastern part of the state of Acre, which is in the southwestern part of the Amazon region $\left(9^{\circ} 08^{\prime} 46.7^{\prime \prime} \mathrm{S} ; 69^{\circ} 01^{\prime} 17.7^{\prime \prime} \mathrm{W}\right)$.

Thirty birds were caught, from which 22 feces samples were collected. The collections were carried out twice a week from January to March 2017, using five mist nets measuring $12 \mathrm{~m}$ long (each net) and $2.5 \mathrm{~m}$ high, with mesh size of $36 \mathrm{~mm}$. The nets were opened in the morning and afternoon in two different ecosystems of the reserve: (a) open areas (anthropic), close to dwellings; and (b) areas covered by primary forest, secondary forest and cleared areas. After capture, the specimens were identified and put into cloth bags for 30 minutes to collect feces and then were released back to nature. The fecal samples were stored in collectors and sent to the Laboratório de Suporte em Vida Selvagem of the Universidade Federal do Acre (UFAC), where the parasitological tests were carried out. 
The parasitological diagnosis was made by means of direct examination of the feces samples under an optical microscope, with staining of the samples using Lugol's solution; and by the $\mathrm{NaCl}$ solution centrifugal flotation method, using 10X and 40X objective lenses (Olympus CX40). The parasites were identified in accordance with Foreyt (2005) and Zajac \& Conboy (2006).

The specimens studied were collected under authorization from the Ethics Committee for Animal Use of the UFAC, through protocol no. 2107.009788/2016-01, and from the Authorization and Information System on Biodiversity (SISBIO), no. 67436297. Statistical analyzes were performed using OpenEpi version 3 software, using Clopper-Pearson confidence interval (1934).

\section{Results and Discussion}

Among the feces samples collected, $63.63 \%(n=14)$ were positive for gastrointestinal parasites. Five types of endoparasites were identified (Table 1; Figure 1).

Table 1. Endoparasite frequency distribution found among 14 fecal samples from Ramphocelus carbo specimens that were caught in the Reserva Extrativa de Cazumbá-Iracema in Sena Madureira, Acre.

\begin{tabular}{ccc}
\hline Parasites & Prevalence (\%) & IC 95 (\%) \\
\hline Isospora spp. (Eimeriidae) & 57.14 & $32.59-78.62$ \\
\hline Entamoeba spp.(Endamoebidae) & 7.14 & $1.272-31.47$ \\
\hline Davaneidae (Cestoda) & 14.28 & $4.01-39.94$ \\
\hline Ascaridiidae (Nematoda) & 35.71 & $16.35-61.23$ \\
\hline Strongylida (Nematoda) & 7.14 & $1.272-31.47$ \\
\hline
\end{tabular}



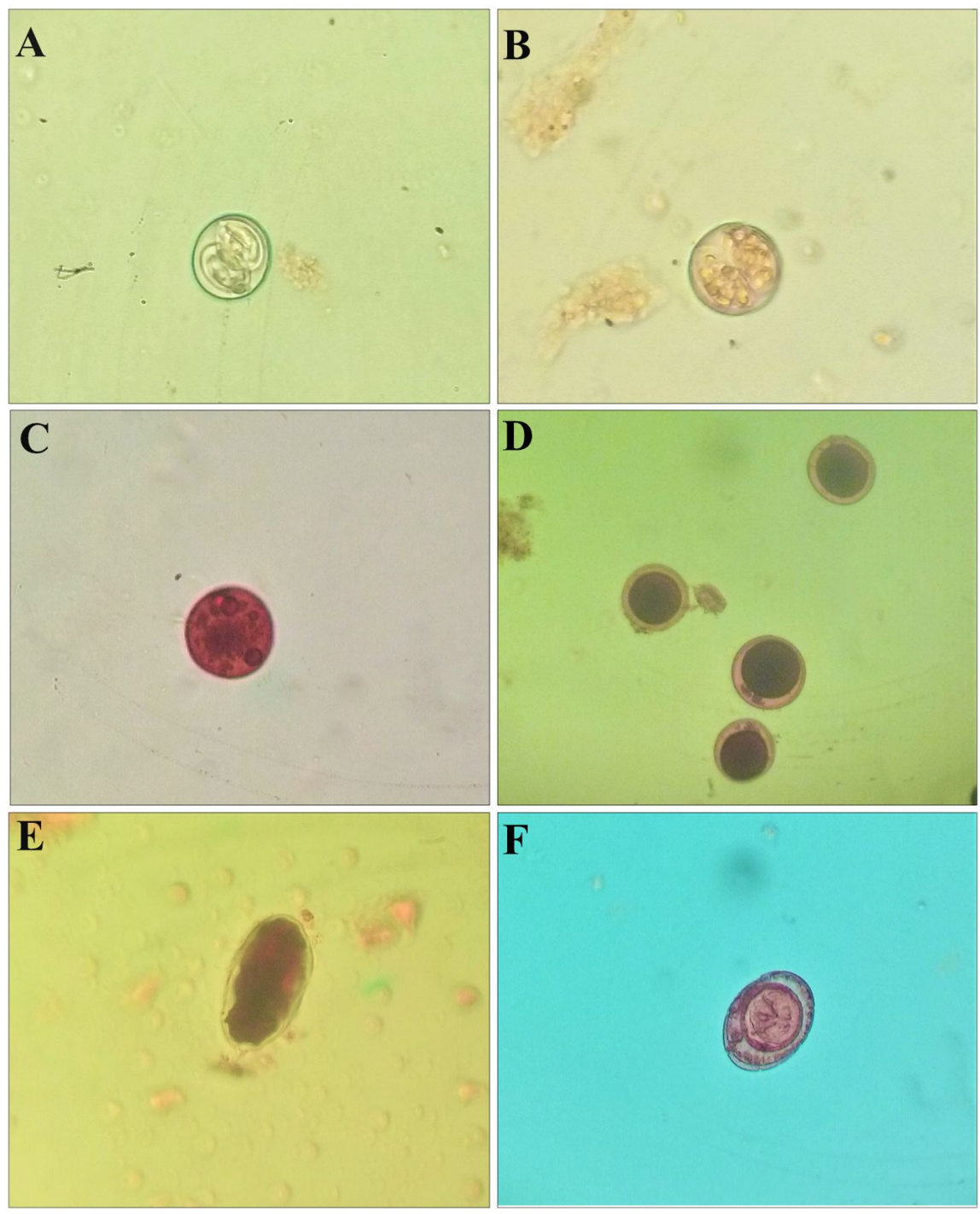

Figure 1. Endoparasites found in the feces of Ramphocelus carbo specimens that were caught in the Reserva Extrativa do Cazumbá-Iracema, Acre. (A-B) Oocysts of Isospora spp.; (C) Cysts of Entamoeba spp.; (D) Eggs of Ascaridiidae; (E) Egg of Strongylida; (F) Eggs of Davaneidae. Figures photographed in saturated $\mathrm{NaCl}$ solution and stained with Lugol (40X lenses).

The presence of coccidia in $R$. carbo feces was reported by Boughton (1938) in their study on host birds of the genus Isospora. These protozoa were also found in $R$. bresilius in southeastern Brazil (Berto et al., 2008; Berto et al., 2009; Berto, 2010; Berto et al., 2010a,b; Berto et al., 2011; Lopes et al., 2013). Brito et al. (2017) also found individuals of $R$. carbo parasitized by Isospora and Entamoeba on the campus of the UFAC, and these data corroborate the results from the present study. According to Lopes et al. (2013), just like other vertebrates, Passerines can be parasitized by Coccidia, among which the genus Isospora was considered to be the most significant, followed by the genus Eimeria. Birds of the family Thraupidae have similar habitats and ecological niches (Piacentini et al., 2015; Sick, 1997). Transmission of parasites among these birds is easy: not only because of their foraging habits but also because the presence of a huge number of bird species in diverse ecosystems ensures wide distribution of these parasites (Berto et al., 2009; Berto, 2010). 
In the present study, parasites like Ascaridiidae, Davaneidae and Strongylida were recorded for the first time in Ramphocelus in the State of Acre, since they were not found by Brito et al. (2017). Among the 193 fecal samples that they analyzed, only 2.59\% (5/193) were from $R$. carbo and these were parasitized with oocysts of Eimeria spp. and Isospora sp. and by cysts of Entamoeba histolytica. In the same study, the authors found eggs of ascarids and strongylids in other Passerine species. Eggs of Choanotaenia spp. were found in a species of Thaupidae (Tangara episcopus). Souza et al. (2019) found samples of Sporophila caerulescens (Thaupidae) parasitized by oocysts Coccidia, cysts of E. coli and E. histolytica and eggs of Davaineidae. These data suggest a possible source of infection among bird species in the region.

Wild specimens of Ramphocelus passerinii in southern Costa Rica were reported to have the presence of Capillaria and ascarids eggs (Rojas, 2016). However, eggs of parasites belonging to Strongylida and Davaneidae were first recorded in a species of Ramphocelus in the present study.

Infected individuals of the species $R$. carbo can generate numerous health problems affecting a diversity of birds and, most probably, other organisms related to them (Costa et al., 2010; Berto et al., 2008, 2009; Brito et al., 2017; Freitas et al., 2002; Marietto-Goncalves et al., 2009; Souza et al., 2019). New molecular research techniques need to be implemented so that such findings can become increasingly reliable and authoritative.

\section{Conclusion}

This study recorded occurrences of protozoa and helminths in $R$. carbo in the Amazon region, from where there are very few parasitological studies on wild birds.

\section{Acknowledgements}

The authors would like to thank Prof. Dr. Silvia Maria Mendes Ahid of the Universidade Federal Rural do Semi-Árido (UFERSA) for her support in confirming the identification of the parasites; and to give special thanks to the residents of the Cazumbá Resex for their support in catching the birds.

\section{References}

Berto BP, Flausino W, Luz HR, Ferreira I, Lopes CWG. Three new Coccidian parasites of Brazilian tanager (Ramphocelus bresilius dorsalis) from South America. Acta Protozool 2008; 47(1): 77-81.

Berto BP, Flausino W, Luz HR, Ferreira I, Lopes CWG. Two new Isospora species from Brazilian tanager (Ramphocelus bresilius dorsalis) of South America. Parasitol Res 2009; 105(3): 635-639. http://dx.doi.org/10.1007/s00436-009-1432-y. PMid:19399519.

Berto BP, Flausino W, Luz HR, Ferreira I, Lopes CWG. Isospora ramphoceli n. sp. (Apicomplexa: Eimeriidae) from the Brazilian tanager (Aves: Passeriformes: Thraupidae) Ramphocelus bresilius dorsalis Sclater, 1855. Zootaxa 2010a; 2650(1): 57-62. http://dx.doi.org/10.11646/zootaxa.2650.1.5.

Berto BP, Luz HR, Ferreira I, Flausino W, Lopes CWG. Two new hosts for Isospora tiesangui Berto, Flausino, Luz, Ferreira \& Lopes, 2008 (Apicomplexa: eimeriidae). Rev Bras Med Vet 2010b; 32(3): 168-171.

Berto BP. Morfologia e Sistemática de coccídios (Apicomplexa: Eimeriidae) parasitas de aves passeriformes da ilha da Marambaia, Rio de Janeiro, Brasil [tese]. Rio de Janeiro: Universidade Federal Rural do Rio de Janeiro; 2010.

Berto BP, Luz HR, Flausino W, Teixeira-Filho WL, Ferreira I, Lopes CWG. Isosporoid Coccidia (Apicomplexa: Eimeriidae) parasites of Tanagers (Passeriformes: Thraupidae) from the Marambaia Island, Brazil. Pesq Vet Bras 2011; 31(9): 798-805. http://dx.doi.org/10.1590/S0100736X2011000900012. 
Boughton DC, Boughton RB, Volk J. Avian hosts of the genus Isospora (Coccidiida). Ohio J Sci 1938; 38(3): 149-163.

Brito ASA, Guilherme E, Santos FGA, Mesquita RP, Gomes FA. Endoparasites of wild birds from campus area and Zoobotanical Park, at the Federal University of Acre, Rio Branco - Acre. Arq Ciênc Vet Zool UNIPAR 2017; 20(3): 117-122. http://dx.doi.org/10.25110/arqvet.v20i3.2017.6363.

Carvalho CT. Notas sobre a biologia do Ramphocelus carbo (Passeriformes: thraupidae). Bol Mus Para Emilio Goeldi 1957; 5(1): 1-20.

Costa IA, Coelho CD, Bueno C, Ferreira I, Freire RB. Ocorrência de parasitos gastrintestinais em aves silvestres no município de Seropédica, Rio de Janeiro, Brasil. Cienc Anim Bras 2010; 11(4): 914922. http://dx.doi.org/10.5216/cab.v11i4.7164.

Foreyt WJ. Parasitologia veterinária: manual de referência. São Paulo: Roca; 2005.

Freitas MFL, Oliveira JB, Cavalcanti MDB, Leite AD, Magalhães VS, Oliveira RA, et al. Parásitos gastrointestinales de aves silvestres en cautiverio en el Estado de Pernambuco, Brasil. Parasitol Latinoam 2002; 57(1-2): 50-54.

Guilherme E. Aves do Acre. Rio Branco: Edufac; 2016.

Hilty S. Silver-beaked Tanager (Ramphocelus carbo). In: Del Hoyo J, Elliott A, Sargatal J, Christie DA, Juana $\mathrm{E}$, editors. Handbook of the birds of the world alive. Barcelona: Lynx Edicions; 2018.

Lopes BB, Berto BP, Ferreira I, Luz HR, Lopes CWG. Coccidial distribution from passerines in an area of Atlantic Forest in Marambaia Island, Rio de Janeiro, Brazil. Coccidia 2013; 1(1): 10-16.

Marietto-Goncalves A, Martins TF, Lima ET, Lopes RS, Andreatti FRL. Prevalência de endoparasitas em amostras fecais de aves silvestres e exóticas examinadas no Laboratório de Ornitopatologia e no Laboratório de Enfermidades Parasitárias da FMVZ-UNESP/Botucatu-SP. Cienc Anim Bras 2009; 10(1): 349-354.

Piacentini VQ, Aleixo A, Agne CE, Mauricio GN, Pacheco JF, Bravo GA, et al. Annotated checklist of the birds of Brazil by the Brazilian Ornithological Records Committee. Rev Bras Ornitol 2015; 23(2): 91-298.

Rojas MG. Presencia de parásitos en aves silvestres (Orden Passeriforme) de vida libre de la zona sur de Costa Rica [trabalho de conclusão de curso]. Costa Rica: Universidad Nacional; 2016.

Sick H. Ornitologia Brasileira. Rio de Janeiro: Nova Fronteira; 1997.

Souza LS, Guilherme E, Andrade AMF, Santos FGA. Occurrence of endo and hemoparasites in Sporophila caerulescens captured in the eastern region of the state of Acre, Brazil. Cienc Rural 2019; 49(4): e20180811. http://dx.doi.org/10.1590/0103-8478cr20180811.

Zajac AM, Conboy GA. Veterinary clinical parasitology. Ames: Blackwell Publishing; 2006. 